\title{
INVESTIGATION OF PARENTS' OPINIONS ABOUT DISTANCE EDUCATION DURING THE COVID-19 PANDEMIC
}

\author{
Dr. Engin DEMIR \\ ORCID: 0000-0002-6280-5467 \\ Department of Child Care and Youth Services \\ Bandirma Onyedi Eylul University \\ Balikesir, TURKEY \\ Dr. Cennet GOLOGLU DEMIR \\ ORCID: 0000-0002-8770-6107 \\ Department of Child Development \\ Bandirma Onyedi Eylul University \\ Balikesir, TURKEY
}

Received: 29/06/2020 Accepted: 22/09/2020

\begin{abstract}
The purpose of the current study is to investigate the distance education given via the Education Information Network platform, TRT EBA-TV and EBA live lesson during the Covid-19 pandemic on the basis of parents' opinions. The current study employing the survey model was conducted with the participation of 709 parents. The research data were collected by an online questionnaire prepared by the researchers. Descriptive statistics were used to analyze the data. As a result of the study, it was determined that during the distance education process, parents ensured that their children followed the lessons and motivated them, and students were eager to participate in the lessons. It was determined that student motivation was negatively affected for reasons such as connection problems and being closed at home during the pandemic. Parents stated that their awareness of their children's education increased and they better understood the value of the teacher and school. It was revealed that there were technical problems in the process but support was received for the problems encountered. Though the parents think that face-to-face education cannot be replaced by distance education, they are of the opinion that distance education was good during the pandemic so that their children did not get alienated from the school.
\end{abstract}

Keywords: Distance education, EBA, Covid-19, pandemic, parents.

\section{INTRODUCTION}

According to the data of the World Health Organization (WHO, 2020), millions of people have been infected and hundreds of thousands of people have died due to the Covid-19 pandemic that has spread worldwide. According to the data issued by UNESCO (2020a), it affected more than 800 million learners worldwide. Almost all countries have taken a series of precautions across the globe to reduce the speed of the spread of the virus and especially to prevent the health system from being overloaded. One of these measures was to temporarily suspend face-to-face education in schools and universities. Education at school has been completely suspended in most of the European countries and locally suspended in some others since March 16, 2020. This caused disruption in education worldwide. Countries have brought distance education to the forefront using various national education portals (UNESCO, 2020b) to help students overcome this process with minimal damage. One of these countries is Turkey.

The first Covid-19 case was announced to be seen in Turkey on March 11, 2020 by the Ministry of Health. After this announcement, face-to-face education was suspended on March 16, 2020, and it was decided to continue the education of primary, secondary, high school and university students through distance education as of March 23, 2020. Thus, a total of 10 million primary and secondary school students (Ministry 
of National Education [MoNE], 2020a) started to continue their education with distance education due to the pandemic. Many governments worldwide have instructed their institutions to continue education online (Daniel, 2000).

With the suspension of education in schools, distance education process was immediately initiated all over Turkey at the same time in order for students not to stay away from education for a long time. Then, people under the age of 20 were prohibited from going out on April 3, 2020. Therefore, students could not leave their houses. Universities and private schools continued their distance education through their distance education infrastructure. The MoNE conducts distance education in public schools via the Education Information Network [EBA] platform, Turkish Radio and Television Corporation [TRT] EBA TV and EBA live lessons.

The purpose of the EBA platform is to support effective material use through information technologies and to integrate technology into education. The EBA platform consists of five main components; 1) Educational search engine 2) Educational content 3) Effective use of IT in curriculums 4) In-service training for teachers 5) Ensuring conscious and secure IT usage by providing the required network infrastructure and broadband internet. The EBA platform has been updated since 2012 and used in distance education (MoNE, 2020b). In its most recent version, teachers can use features such as classroom wall and school wall as a social media environment to interact with students they teach, share activities, ask questions, start discussions and send questionnaires. In EBA, which is defined as a social education platform, many education services are offered together under the names of news, e-content, e-journal, e-book, video, audio, visual, document, let's discuss and EBA market. The curriculum of the Turkish National Education System forms the basis of the EBA platform. The EBA platform is accessible to students, teachers, parents and educational scientists and is free of charge.

TRT EBA TV is a distance education platform established with the cooperation of the MoNE and the TRT to be consisted of three separate channels: TRT EBA TV primary school, TRT EBA TV middle school and TRT EBA TV high school. Students can follow the courses, which are broadcast twice a day, at the appropriate time for their own level of schooling. Lessons are delivered during the week. There are also programs to inform parents. It is possible to access and log in to the EBA platform via an internet browser or mobile application. Through this platform, students can participate in live lessons (EBA live lessons) given by their school teachers. In addition, homework assignments and other educational activities given by teachers are performed through the EBA platform by students.

The distance education conducted in public schools in Turkey does not differ by school or region (city). It can be said that one of the most important differences of distance education during the pandemic from the distance education given in normal periods is that parents who have to stay at home for reasons such as flexible / distance working, closed workplaces or anxiety to go out participate in the educational process of their children. When the literature is reviewed, it is seen that the existing research about the EBA platform is focused on teachers and students (Aktay \& Keskin, 2016; Ates et al. 2015; Coskunserce \& Isciturk, 2019; Kapidere \& Cetinkaya, 2017; Saklan \& Unal, 2018; Sahin \& Erman, 2019; Turker \& Guven, 2016; Tuysuz \& Cumen, 2016). Research results show that teachers do not use the EBA platform frequently, yet they consider the EBA platform necessary. Huang et al. (2020), in their large-scale reports, discussed the components of distance and flexible learning in all aspects in China, as a result of interruption of education due to the Covid-19 pandemic. There is no study in the literature that examines the views of parents about the education of their children and the distance education their children receive during the Covid-19 pandemic. For these reasons, it is thought that the evaluation of distance education through the eyes of parents during the pandemic will contribute to the literature. Moreover, the results of the current study may be useful for preventing other countries from committing possible mistakes in distance education.

\section{PURPOSE OF THE STUDY}

The purpose of the current study is to determine parents' opinions about distance education (EBA platform, TRT EBA-TV, EBA live lesson) during the pandemic. To this end, answers to the following questions were sought;

1. What are the parents' interest in distance education and their opinions on child follow-up?

2. What are the parents' opinions about their children's interest in distance education? 
3. What are the parents' opinions about their awareness of distance education?

4. What are the parents' opinions about the home environment and access to distance education?

5. What are the parents' general opinions about distance education?

\section{METHOD}

\section{Research Model}

The current study employing the qualitative research model is designed according to the survey model. "Survey models are research approaches aiming to describe a past or present state as it was or is. The event, individual or object being researched is attempted to be described in its own conditions as it is. There is no intention to change or affect it in any way" (Karasar, 2019, p.109).

\section{Population and Sample}

Population of the current study is comprised of parents at least one of whose children attends a state elementary or secondary school in Turkey. According to the statistics issued by the MoNE, the total number of students attending elementary and secondary state schools in Turkey in the 2018-2019 school year is $10,104,489$. Since the research was conducted with parents and only one of the parents would be included in the study, the sample size was calculated by accepting the number of parents as $10,104,489$. In order to calculate the sample size, an application was conducted with a group of 45 people. The sample size was calculated by using $\sigma=1,25, d=0,1$ and $z_{\sigma / 2}=1.96$ for $a=0.05$ (Karagoz, 2019):

$$
n=\frac{N \cdot \sigma^{2} \cdot z_{\sigma / 2}^{2}}{d^{2}(N-1)+\sigma^{2} \cdot z_{\sigma / 2}^{2}}
$$

$\mathrm{n}=$ Sample size

$\sigma=$ Standard deviation of the main mass

$\mathrm{d}=$ Amount of deviation for the estimation of median

$z_{\sigma / 2}=$ Theoretical value found according to $\mathrm{Z}$ table at a certain significance level.

$\mathrm{N}=$ Main mass

When all these values were placed in the formula in MS Excell, the sample size for the current study was found to be $n=609.84$. The sample of the current study was selected by using the convenience sampling method, one of the non-probability sampling methods. In the convenience sampling method, the sample is constructed starting with the most available respondents. An important limitation to be noted here is that the use of non-probability sampling in studies conducted with online surveys reduces the generalizability of the findings (Cohen, Manion \& Morrison, 2018).

In elementary and secondary school levels, teachers usually constitute parent groups via WhatsApp to communicate with parents quickly and personally. In this connection, the researchers sent online questionnaires to parents via WhatsApp Parent Groups, with the support of the heads of parent-school associations and parents from different provinces. EB, mentioned in the first part of the current study, was planned as a distance education platform for students in public schools in Turkey. Private schools use different infrastructures. In addition, in order for the questionnaire items to be answered in a healthy way, parents should use all three platforms for distance education. Based on the idea that high school students act more independently from their parents, the criteria for inclusion and not inclusion in the current study were determined.

\section{Criteria for inclusion in the study}

- At least one of the parents' children should be attending an elementary or secondary school

- At least one of the parents' children should be attending a state school

- At least one of the parents' children should be following TRT-EBA TV, EBA platform and EBA live lesson 


\section{Criteria for not inclusion in the study}

- Child/children of the parents should be attending a private school

- Child/children of the parents should be attending a high school or university

- Child/children of the parents should not be following all the lessons in TRT-EBA TV, EBA platform and EBA live lessons

Within the scope of the current study, a total of 1375 parents were reached online. Instead of giving a detailed explanation of the criteria of inclusion in the current study in the online form instruction, an approach was adopted in the form of exclusion by obtaining information from the parents before the analysis was initiated. The reason for adopting this approach is the possibility that parents might not read the online survey instruction carefully. Thus, those that should have been outside the scope of the research were prevented from being included in the analysis. After the data that did not meet the inclusion criteria were excluded from the analysis, the study was conducted on a total of 709 parents. The socio-demographic features of the parents are given in Table 1:

Table 1. Socio-demographic features of the parents

\begin{tabular}{|c|c|c|}
\hline Gender & Frequency (N) & Percentage (\%) \\
\hline Female & 574 & 81.0 \\
\hline Male & 135 & 19.0 \\
\hline Age & Frequency (N) & Percentage (\%) \\
\hline Under 25 & 18 & 2.5 \\
\hline $25-34$ & 129 & 18.2 \\
\hline $35-44$ & 437 & 61.6 \\
\hline $45-54$ & 120 & 16.9 \\
\hline $55-64$ & 5 & .7 \\
\hline Education level & Frequency (N) & Percentage (\%) \\
\hline Elementary & 94 & 13.3 \\
\hline Secondary & 106 & 15.0 \\
\hline High school & 213 & 30.0 \\
\hline Undergraduate & 266 & 37.5 \\
\hline Graduate & 30 & 4.2 \\
\hline Profession & Frequency (N) & Percentage (\%) \\
\hline Housewife & 331 & 46.7 \\
\hline Civil servant & 158 & 22.3 \\
\hline Worker & 79 & 11.1 \\
\hline Tradesman & 36 & 5.1 \\
\hline Retired & 15 & 2.1 \\
\hline Framer (Agriculture and Animal Husbandry) & 4 & 6 \\
\hline Unemployed & 19 & 2.7 \\
\hline Others & 67 & 9.4 \\
\hline Income level & Frequency (N) & Percentage (\%) \\
\hline $2500 \mathrm{TL}$ and less & 145 & 20.5 \\
\hline $2500-5000$ & 294 & 41.5 \\
\hline $5001-7500$ & 136 & 19.2 \\
\hline $7500 \mathrm{TL}$ and more & 134 & 18.9 \\
\hline
\end{tabular}

When Table 1 is analyzed, it is seen that the majority of the parents $(81.0 \%)$ participating in the study are women and in the 35-44 age group (61.6\%). It is seen that the majority of the teachers have undergraduate 
(37.5\%) and high school (30.0) education. Nearly half of the participating parents are housewives (46.7\%), followed by civil servants $(22.3 \%)$ and workers $(11.1 \%)$. When the income levels of the parents are examined, it is seen that nearly half of the parents (41.5\%) have 2500-5000 monthly income while the remaining parents are equally distributed across the other income levels. In 2020 the minimum wage in Turkey was determined to be 2324.70 ; that is, approximately $\$ 342$. In this regard, $20.5 \%$ of the participants have income lower than this minimum wage.

\section{Development of the Data Collection Tool}

A questionnaire was developed by the researchers to collect the research data. While developing the questionnaire, first the existing research in the literature on the subject of distance education was reviewed (Aktay \& Keskin, 2016; Berge, 2013; Bilgic \& Tuzun, 2015; de Oliveira, 2018; Coskunserce \& Isciturk, 2019; Liu, 2002). Then, a questionnaire containing 5 open-ended questions was sent to 10 parents that the researcher could easily reach by e-mail and the answers were received by e-mail. These questions are:

- What are the responsibilities of father / mother in terms of following their children's distance education activities? What did you do in this regard?

- How do you evaluate your children's interest and motivation to follow their lessons during the distance education process? What did you do as a parent in this regard?

- What are the problems you have experienced as a parent during the distance education process (if any)? How did you cope with these problems?

- What are the positive / negative aspects of distance education?

- What are your general opinions about the distance education process conducted during the pandemic? Table 2 gives examples of the questionnaire items written in line with the opinions of the parents. Only one of the similar parent opinions is given.

Table 2. Examples of the questionnaire items written in line with the opinions of the parents

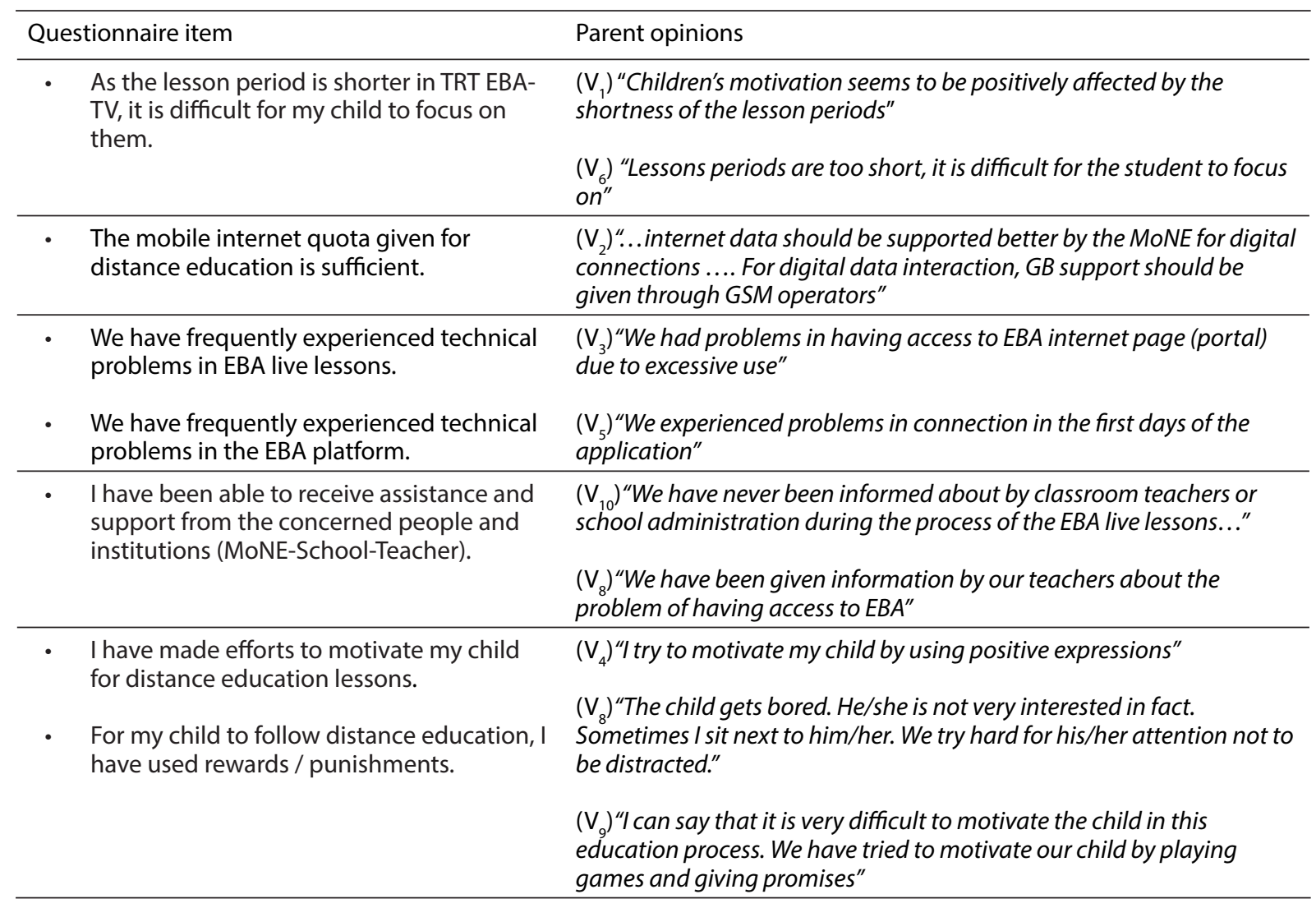


- During the pandemic, my child is not alienated to the school because of distance education.

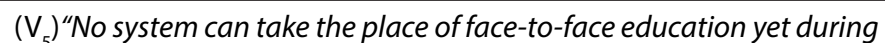
such a process, at least our children stay connected to school, partially experience the school environment; thus, it is useful, in my opinion"
- Delivery of the lessons in the virtual environment makes it difficult for me to control my child's internet use outside the lessons.
$\left(\mathrm{V}_{5}\right)^{\prime \prime} T$ The fact that there are lessons continuously delivered in the virtual environment makes it difficult for us to control the internet usage of our children outside the lesson periods"

Finally, taking into account the researchers' own observations in the process, a five-point Likert-type questionnaire having 38 items was constructed to elicit the parents' opinions about "their interest in distance education and following their children", "interest of their children in distance education", "development of awareness about education", "home environment and access to distance education" and their general opinions.

For the content validity of the questionnaire, opinions of two teachers; one with a master's degree in computer and instructional technologies and the other in a psychological counselling and guidance, were sought. The experts were given the expert opinion form designed as a four-point Likert scale (1=Not suitable at all, $2=$ Major revision is needed, $3=$ Minor revision is needed, $4=$ Completely suitable). They were asked to provide short explanations about the items they did not find suitable. Krippendorff alpha reliability coefficient showing the consistency between four evaluators was calculated to be .82 . This shows that there is a high consistency between the four evaluators. In line with the feedbacks given by the experts, four items were corrected and six items were discarded from the questionnaire. The corrected four items were submitted to the expert review once more. Lyn (1986) states than when the number of the experts is under five, then the experts should be in agreement. Thus, a total of 32 items on which the experts agreed (they assigned 3 and 4 points) are included in the questionnaire.

An online questionnaire was sent to nine parents and a Turkish teacher to minimize the problems that may arise in the actual application. Then the parents were called by phone and their opinions about the questionnaire were taken. Opinions of the experts, parents and Turkish teacher regarding face validity were obtained. Finally, the questionnaire of parents' perceptions of distance education during the pandemic including items to elicit demographic information and 32 items was constructed.

\section{Data Collection and Ethics}

The data of the current study were collected by using the online survey technique. The reason for the selection of this technique is the isolation measures taken in the pandemic. In addition, it was attempted to reach parents with the help of parent-school association and parents in order to obtain reliable data. WhatsApp parent groups in Turkey made it easier to reach parents. The data were collected through an online questionnaire designed by using the Google Forms. In the first page of the online form, information is given about the purpose of the study. In the second page, there is the informed consent form. When the participants pressed the button "I have read and understood", they went on with the questionnaire items. The study was approved by ethics committee.

\section{Data Analysis}

In the analysis of the data collected online, descriptive statistics such as means, standard deviations, frequencies and percentages were used for individual items. In the evaluation of item means, the following criteria were taken into consideration. 
Table 3. Criteria to Evaluate Item Means

\begin{tabular}{ll}
\hline Group Intervals & Scale \\
\hline $1.00-1.79$ & Strongly disagree \\
$1.80-2.59$ & Disagree \\
$2.60-3.39$ & Partially agree \\
$3.40-4.19$ & Agree \\
$4.20-5.00$ & Strongly agree \\
\hline
\end{tabular}

While interpreting the tables on the basis of the evaluation criteria, the options "Strongly disagree" and "Disagree" were evaluated by the researchers as the respondents' disagreeing with the given statement while the options "Partially agree", "Agree" and "Strongly agree" were evaluated as the respondents' agreeing with the given statement.

\section{FINDINGS}

The findings obtained for the sub-problems of the current study are presented in the order specified by the sub-problems. By using the data collected from the parents, frequencies, percentages means and standard deviations for each item were calculated and are presented here. In relation to the first sub-problem of the study, the opinions about the parents' interest in distance education and following their children are presented in Table 4.

Table 4. Interest in distance education and following children

\begin{tabular}{|c|c|c|c|c|c|c|c|c|c|c|c|c|}
\hline & \multicolumn{2}{|c|}{$\begin{array}{l}\text { Strongly } \\
\text { Disagree }\end{array}$} & \multicolumn{2}{|c|}{ Disagree } & \multicolumn{2}{|c|}{$\begin{array}{l}\text { Partially } \\
\text { Agree }\end{array}$} & \multicolumn{2}{|c|}{ Agree } & \multicolumn{4}{|c|}{$\begin{array}{l}\text { Strongly } \\
\text { Agree }\end{array}$} \\
\hline & $\mathrm{n}$ & $\%$ & $\mathrm{n}$ & $\%$ & $\mathrm{n}$ & $\%$ & $\mathrm{n}$ & $\%$ & $\mathrm{n}$ & $\%$ & $\bar{x}$ & Ss \\
\hline $\begin{array}{l}\text { 1. I have had difficulty in following what } \\
\text { is done within the context of distance } \\
\text { education activities. }\end{array}$ & 237 & 33.4 & 129 & 18.2 & 185 & 26.1 & 79 & 11.1 & 79 & 11.1 & 2.48 & 1.34 \\
\hline $\begin{array}{l}\text { 2. I have not been adequately } \\
\text { interested in the process of distance } \\
\text { education. }\end{array}$ & 395 & 55.7 & 108 & 15.2 & 89 & 12.6 & 47 & 6.6 & 70 & 9.9 & 1.99 & 1.35 \\
\hline $\begin{array}{l}\text { 3. I am following how my child } \\
\text { conducts distance education activities. }\end{array}$ & 14 & 2.0 & 17 & 2.4 & 49 & 6.9 & 123 & 17.3 & 506 & 71.4 & 4.53 & .87 \\
\hline $\begin{array}{l}\text { 4. I helped my child to follow his/her } \\
\text { lessons in the correct times. }\end{array}$ & 20 & 2.8 & 12 & 1.7 & 34 & 4.8 & 97 & 13.7 & 546 & 77.0 & 4.60 & .88 \\
\hline $\begin{array}{l}\text { 5. I have made efforts to motivate my } \\
\text { child for distance education lessons. }\end{array}$ & 19 & 2.7 & 8 & 1.1 & 42 & 5.9 & 115 & 16.2 & 525 & 74.0 & 4.57 & .86 \\
\hline $\begin{array}{l}\text { 6. Delivery of the lessons in the virtual } \\
\text { environment makes it difficult for me to } \\
\text { control my child's internet use outside } \\
\text { the lessons. }\end{array}$ & 248 & 35.0 & 71 & 10.0 & 137 & 19.3 & 100 & 14.1 & 153 & 21.6 & 2.77 & 1.56 \\
\hline $\begin{array}{l}\text { 7. For my child to follow distance } \\
\text { education, I have used rewards / } \\
\text { punishments. }\end{array}$ & 473 & 66.7 & 58 & 8.2 & 80 & 11.3 & 38 & 5.4 & 60 & 8.5 & 1.80 & 1.31 \\
\hline $\begin{array}{l}\text { I have had some problems with my } \\
\text { child in terms of his/her following } \\
\text { distance education as he/she behaves } \\
\text { indifferently in this subject. }\end{array}$ & 271 & 38.2 & 74 & 10.4 & 153 & 21.6 & 83 & 11.7 & 128 & 18.1 & 2.60 & 1.52 \\
\hline
\end{tabular}

When the parents' opinions shown in Table 4 in relation to "interest in distance education and following children" are examined considering the means, it is seen that the parents stated that they disagree with the items "I have had difficulty in following what is done within the context of distance education 
activities" ( $\overline{\mathrm{x}}=2.48)$; "I have not been adequately interested in the process of distance education" $(\overline{\mathrm{x}}=1.99)$; "For my child to follow distance education, I have used rewards / punishments" ( $\overline{\mathrm{x}}=1.80)$. On the other hand, it is seen that they partially agree with the items "Delivery of the lessons in the virtual environment makes it difficult for me to control my child's internet use outside the lessons" ( $\bar{x}=2.77)$; "I have had some problems with my child in terms of his/her following distance education as he/she behaves indifferently in this subject" $(\bar{x}=2.60)$. Yet, the parents were found to strongly agree with the items "I am following how my child conducts distance education activities" ( $\overline{\mathrm{x}}=4.53)$, "I helped my child to follow his/her lessons in the correct times" ( $\overline{\mathrm{x}}=4.60)$; "I have made efforts to motivate my child for distance education lessons" $(\overline{\mathrm{x}}=4.57)$.

When the parents' opinions shown in Table 4 are examined considering percentages and frequencies, it is seen that $70.9 \%$ of the parents have been adequately interested in the process of distance education, that 95.6\% of them follow how their children conduct distance education activities; that $95.5 \%$ of them helped their children to follow their lessons in correct times, that $96.1 \%$ of them have made efforts to motivate their children for distance education lessons, that $74.9 \%$ of them have not used rewards / punishments for their children to follow distance education. In relation to the second sub-problem of the study, the parents' opinions about their children's interest in distance education are given in Table 5.

Table 5. Children's interest in distance education

\begin{tabular}{|c|c|c|c|c|c|c|c|c|c|c|c|c|}
\hline & \multicolumn{2}{|c|}{$\begin{array}{l}\text { Strongly } \\
\text { Disagree }\end{array}$} & \multicolumn{2}{|c|}{ Disagree } & \multicolumn{2}{|c|}{$\begin{array}{l}\text { Partially } \\
\text { Agree }\end{array}$} & \multicolumn{2}{|c|}{ Agree } & \multicolumn{4}{|c|}{$\begin{array}{l}\text { Strongly } \\
\text { Agree }\end{array}$} \\
\hline & $\mathrm{n}$ & $\%$ & $\mathrm{n}$ & $\%$ & $\mathrm{n}$ & $\%$ & $\mathrm{n}$ & $\%$ & $\mathrm{n}$ & $\%$ & $\bar{x}$ & Ss \\
\hline $\begin{array}{l}\text { 1. My child is willing to } \\
\text { participate in EBA live } \\
\text { lessons. }\end{array}$ & 35 & 4,9 & 35 & 4,9 & 101 & 14,2 & 124 & 17,5 & 414 & 58,4 & 4,19 & 1,15 \\
\hline $\begin{array}{l}\text { 2. My child is willing to } \\
\text { participate in TRT EBA-TV } \\
\text { lessons. }\end{array}$ & 63 & 8.9 & 62 & 8.7 & 171 & 24.1 & 142 & 20.0 & 271 & 38.2 & 3.69 & 1.29 \\
\hline $\begin{array}{l}\text { 3. My child is willing to } \\
\text { do the activities and } \\
\text { assignments in the EBA } \\
\text { platform. }\end{array}$ & 58 & 8.2 & 58 & 8.2 & 155 & 21.9 & 161 & 22.7 & 277 & 39.1 & 3.76 & 1.27 \\
\hline $\begin{array}{l}\text { 4. My child carefully } \\
\text { follows his/her lessons } \\
\text { until the end. }\end{array}$ & 30 & 4.2 & 33 & 4.7 & 133 & 18.8 & 186 & 26.2 & 327 & 46.1 & 4.05 & 1.10 \\
\hline $\begin{array}{l}\text { 5. As the lesson period is } \\
\text { shorter in TRT EBA-TV, it } \\
\text { is difficult for my child to } \\
\text { focus on them. }\end{array}$ & 225 & 31.7 & 92 & 13.0 & 135 & 19.0 & 97 & 13.7 & 160 & 22.6 & 2.82 & 1.55 \\
\hline $\begin{array}{l}\text { 6. Connection problems } \\
\text { negatively affected the } \\
\text { interest of my child. }\end{array}$ & 133 & 18.8 & 71 & 10.0 & 146 & 20.6 & 110 & 15.5 & 249 & 35.1 & 3.38 & 1.50 \\
\hline $\begin{array}{l}\text { 7. The belief that there } \\
\text { is not going to be any } \\
\text { evaluation decreased my } \\
\text { child's interest in distance } \\
\text { education. }\end{array}$ & 252 & 35.5 & 100 & 14.1 & 145 & 20.5 & 76 & 10.7 & 136 & 19.2 & 2.63 & 1.51 \\
\hline $\begin{array}{l}\text { 8. As my child is closed } \\
\text { at home due to the } \\
\text { pandemic, his/her } \\
\text { motivation for distance } \\
\text { education is negatively } \\
\text { affected. }\end{array}$ & 180 & 25.4 & 87 & 12.3 & 162 & 22.8 & 107 & 15.1 & 173 & 24.4 & 3.00 & 1.50 \\
\hline
\end{tabular}

When the parents' opinions shown in Table 5 in relation to "children's interest in distance education" are examined considering the means, it is seen that the parents stated that they partially agree with the items "Connection problems negatively affected the interest of my child" ( $\bar{x}=3.38)$; "The belief that there is not 
going to be any evaluation decreased my child's interest in distance education" $(\overline{\mathrm{x}}=2.63)$ and "As my child is closed at home due to the pandemic, his/her motivation for distance education is negatively affected" $(\bar{x}=3.00)$. The parents were found to agree with the items "My child is willing to participate in EBA live lessons" ( $\overline{\mathrm{x}}=4.19)$; "My child is willing to participate in TRT EBA-TV lessons" ( $\overline{\mathrm{x}}=3.69)$; "My child is willing to do the activities and assignments in the EBA platform" ( $\overline{\mathrm{x}}=3.76)$; "My child carefully follows his/ her lessons until the end" $(\bar{x}=4.05)$.

When the parents' opinions shown in Table 5 are examined considering percentages and frequencies, it is seen that more than $80 \%$ of the parents stated that their children willingly participated in and followed distance education lessons (items, 1, 2 and 4). Nearly $70 \%$ of the parents stated that connection problems decreased their children's interest. Nearly half of the parents stated that their children's being closed at home and lesson periods' being shorter negatively affected their motivation for distance education. In relation to the third sub-problem of the study, the parents' opinions about the development of awareness of distance education are presented in Table 6.

Table 6. Development of awareness of distance education

\begin{tabular}{|c|c|c|c|c|c|c|c|c|c|c|c|c|}
\hline & \multicolumn{2}{|c|}{$\begin{array}{l}\text { Strongly } \\
\text { Disagree }\end{array}$} & \multicolumn{2}{|c|}{ Disagree } & \multicolumn{2}{|c|}{$\begin{array}{l}\text { Partially } \\
\text { Agree }\end{array}$} & \multicolumn{2}{|c|}{ Agree } & \multicolumn{4}{|c|}{$\begin{array}{l}\text { Strongly } \\
\text { Agree }\end{array}$} \\
\hline & $\mathrm{n}$ & $\%$ & $\mathrm{n}$ & $\%$ & $n$ & $\%$ & $\mathrm{n}$ & $\%$ & $\mathrm{n}$ & $\%$ & $\bar{x}$ & SS \\
\hline $\begin{array}{l}\text { 1. My awareness of my } \\
\text { child's education process has } \\
\text { increased during the distance } \\
\text { education process. }\end{array}$ & 104 & 14.7 & 60 & 8.5 & 163 & 23.0 & 140 & 19.7 & 242 & 34.1 & 3.50 & 1.40 \\
\hline $\begin{array}{l}\text { 2. I have realized what my } \\
\text { child has learned in school } \\
\text { lessons in the process of } \\
\text { distance education. }\end{array}$ & 107 & 15.1 & 57 & 8.0 & 119 & 16.8 & 129 & 18.2 & 297 & 41.9 & 3.63 & 1.46 \\
\hline $\begin{array}{l}\text { 3. I have better understood } \\
\text { the importance of education } \\
\text { at school during the process } \\
\text { of distance education. }\end{array}$ & 23 & 3.2 & 7 & 1.0 & 48 & 6.8 & 62 & 8.7 & 569 & 80.3 & 4.61 & .90 \\
\hline $\begin{array}{l}\text { 4. I have better understood } \\
\text { the importance of teachers } \\
\text { during the process of distance } \\
\text { education. }\end{array}$ & 20 & 2.8 & 10 & 1.4 & 54 & 7.6 & 74 & 10.4 & 551 & 77.7 & 4.58 & .90 \\
\hline
\end{tabular}

When the parents' opinions shown in Table 6 in relation to "awareness of education" are examined considering the means, it is seen that the parents stated that they agree with the items "My awareness of my child's education has increased during the distance education process" ( $\overline{\mathrm{x}}=3.50)$; "I have realized what my child has learned in school lessons in the process of distance education" $(\bar{x}=3.50)$. The parents were found to strongly agree with the items "I have better understood the importance of education at school $(\bar{x}=4.61)$ and teachers $(\bar{x}=4.58)$ during the pandemic.

When the parents' opinions shown in Table 6 are examined considering percentages and frequencies, it is seen that nearly $75^{\prime} \%$ of the parents stated that their awareness of their children and what they learned increased. More than $95 \%$ of the parents stated that they better understood the importance of education at school and teachers. In relation to the fourth sub-problem of the study, the parents' opinions about the home environment and access to distance education are given in Table 7. 
Table 7. Home environment and access to distance education

\begin{tabular}{|c|c|c|c|c|c|c|c|c|c|c|c|c|}
\hline & \multicolumn{2}{|c|}{$\begin{array}{l}\text { Strongly } \\
\text { Disagree }\end{array}$} & \multicolumn{2}{|c|}{ Disagree } & \multicolumn{2}{|c|}{$\begin{array}{l}\text { Partially } \\
\text { Agree }\end{array}$} & \multicolumn{2}{|c|}{ Agree } & \multicolumn{4}{|c|}{$\begin{array}{l}\text { Strongly } \\
\text { Agree }\end{array}$} \\
\hline & $\mathrm{n}$ & $\%$ & $n$ & $\%$ & $\mathrm{n}$ & $\%$ & $\mathrm{n}$ & $\%$ & $\mathrm{n}$ & $\%$ & $\bar{x}$ & Ss \\
\hline $\begin{array}{l}\text { 1. We have had to make } \\
\text { considerable arrangements } \\
\text { in the home environment. }\end{array}$ & 139 & 19.6 & 103 & 14.5 & 136 & 19.2 & 83 & 11.7 & 248 & 35.0 & 3.27 & 1.53 \\
\hline $\begin{array}{l}\text { 2. Physical conditions at } \\
\text { home (desk-computer- } \\
\text { room) are adequate for } \\
\text { distance education. }\end{array}$ & 49 & 6.9 & 44 & 6.2 & 74 & 10.4 & 105 & 14.8 & 437 & 61.6 & 4.18 & 1.24 \\
\hline $\begin{array}{l}\text { 3. Some stimulants (sibling- } \\
\text { noise and other problems) } \\
\text { have distracted the } \\
\text { attention of my child. }\end{array}$ & 242 & 34.1 & 108 & 15.2 & 129 & 18.2 & 94 & 13.3 & 136 & 19.2 & 2.68 & 1.52 \\
\hline $\begin{array}{l}\text { 4. I have been able } \\
\text { to receive assistance } \\
\text { and support from the } \\
\text { concerned people and } \\
\text { institutions (MoNE-School- } \\
\text { Teacher). }\end{array}$ & 123 & 17.3 & 40 & 5.6 & 112 & 15.8 & 123 & 17.3 & 311 & 43.9 & 3.64 & 1.50 \\
\hline $\begin{array}{l}\text { 5. We have frequently } \\
\text { experienced technical } \\
\text { problems in EBA live } \\
\text { lessons. }\end{array}$ & 76 & 10.7 & 76 & 10.7 & 126 & 17.8 & 110 & 15.5 & 321 & 45.3 & 3.73 & 1.39 \\
\hline $\begin{array}{l}\text { 6. We have frequently } \\
\text { experienced technical } \\
\text { problems in the EBA } \\
\text { platform. }\end{array}$ & 97 & 13.7 & 80 & 11.3 & 154 & 21.7 & 110 & 15.5 & 268 & 37.8 & 3.52 & 1.43 \\
\hline $\begin{array}{l}\text { 7. The mobile internet } \\
\text { quota given for distance } \\
\text { education is sufficient. }\end{array}$ & 245 & 34.6 & 53 & 7.5 & 156 & 22.0 & 64 & 9.0 & 191 & 26.9 & 2.86 & 1.61 \\
\hline
\end{tabular}

When the parents' opinions shown in Table 7 in relation to "home environment and access to distance education" are examined considering the means, it is seen that the parents stated that they partially agree with the items "We have had to make considerable arrangements in the home environment" ( $\bar{x}=3.27)$; "Some stimulants (sibling-noise and other problems) have distracted the attention of my child $(\bar{x}=2.68)$ and "The mobile internet quota given for distance education is sufficient" $(\overline{\mathrm{x}}=2.86)$. The parents were found to agree with the items "Physical conditions at home (desk-computer-room) are adequate for distance education" $(\bar{x}=4.18)$; "We have frequently experienced technical problems in EBA live lessons" ( $\overline{\mathrm{x}}=3.73)$; "We have frequently experienced technical problems in the EBA platform" ( $\overline{\mathrm{x}}=3.52)$ and "I have been able to receive assistance and support from the concerned people and institutions (MoNE-School-Teacher)" ( $\overline{\mathrm{x}}=3.64)$.

When the parents' opinions shown in Table 7 are examined considering percentages and frequencies, it is seen that $85 \%$ of the parents stated that the physical conditions in the home environment are adequate. Nearly $75 \%$ of the parents stated that they experienced technical problems and received assistance and support from the concerned people and institutions for the problems they experienced. Nearly $55 \%$ of the parents stated that the mobile internet quota given to children by GSM operators is sufficient for them to follow distance education lessons. In relation to the fifth sub-problem of the study, the parents' general opinions about distance education are given in Table 8. 
Table 8. General opinions about distance education

\begin{tabular}{|c|c|c|c|c|c|c|c|c|c|c|c|c|}
\hline & \multicolumn{2}{|c|}{$\begin{array}{l}\text { Strongly } \\
\text { Disagree }\end{array}$} & \multicolumn{2}{|c|}{ Disagree } & \multicolumn{2}{|c|}{$\begin{array}{l}\text { Partially } \\
\text { Agree }\end{array}$} & \multicolumn{2}{|c|}{ Agree } & \multicolumn{4}{|c|}{$\begin{array}{l}\text { Strongly } \\
\text { Agree }\end{array}$} \\
\hline & $\mathrm{n}$ & $\%$ & $\mathrm{n}$ & $\%$ & $\mathrm{n}$ & $\%$ & $\mathrm{n}$ & $\%$ & $\mathrm{n}$ & $\%$ & $\bar{x}$ & Ss \\
\hline $\begin{array}{l}\text { 1. Distance education may } \\
\text { take the place of face-to-face } \\
\text { education in future. }\end{array}$ & 470 & 66.3 & 45 & 6.3 & 77 & 10.9 & 77 & 10.9 & 72 & 10.2 & 1.87 & 1.38 \\
\hline $\begin{array}{l}\text { 2. Distance education should } \\
\text { be continued after schools } \\
\text { have been opened. }\end{array}$ & 218 & 30.7 & 48 & 6.8 & 145 & 20.5 & 88 & 12.4 & 210 & 29.6 & 3.03 & 1.61 \\
\hline $\begin{array}{l}\text { 3. I think that distance } \\
\text { education is useful for my } \\
\text { child. }\end{array}$ & 112 & 15.8 & 71 & 10.0 & 168 & 23.7 & 125 & 17.6 & 233 & 32.9 & 3.41 & 1.43 \\
\hline $\begin{array}{l}\text { 4. During the pandemic, my } \\
\text { child is not alienated to the } \\
\text { school because of distance } \\
\text { education. }\end{array}$ & 69 & 9.7 & 38 & 5.4 & 141 & 19.9 & 138 & 19.5 & 323 & 45.6 & 3.85 & 1.31 \\
\hline $\begin{array}{l}\text { 5. I think that distance } \\
\text { education is a good } \\
\text { application during the } \\
\text { pandemic. }\end{array}$ & 29 & 4.1 & 16 & 2.3 & 85 & 12.0 & 130 & 18.3 & 449 & 63.3 & 4.34 & 1.04 \\
\hline
\end{tabular}

When the parents' opinions shown in Table 8 in relation to "general opinions about distance education" are examined considering the means, it is seen that the parents stated that they disagree with the item "Distance education may take the place of face-to-face education" $(\bar{x}=1.87)$. The parents were found to partially agree with the item "Distance education should be continued after schools have been opened" ( $\bar{x}=3.03)$; to agree with the items "I think that distance education is useful for my child" $(\overline{\mathrm{x}}=3.41)$ and "During the pandemic, my child is not alienated to the school because of distance education" $(\overline{\mathrm{x}}=3.85)$ and to strongly agree with the item "I think that distance education is a good application during the pandemic" $(\overline{\mathrm{x}}=4.34)$.

When the parents' opinions shown in Table 8 are examined considering percentages and frequencies, it is seen that $70 \%$ of the parents think that distance education will not take the place of face-to-face education and that distance education is useful for children. Nearly $85 \%$ of the parents think that through distance education, their children are not alienated to the school and more than $90 \%$ of them think that distance education is a good application during the pandemic.

\section{DISCUSSIONS AND CONCLUSION}

One of the difficulties experienced because of the COVID-19 outbreak is the suspension of the educational and instructional activities for students, teachers and parents with the closing of schools (Cullinane \& Montacute, 2020). The study of the distance education system, which is offered to millions of students simultaneously in such a period, creates an opportunity for future mass distance education studies. During the pandemic, parents had to take part in the education process of their children who were closed at home. Coordination of all activities related to education, previously coordinated by schools and teachers, was carried out by parents. Parents have taken part in many parts of distance education such as elimination of technical problems related to distance education via the EBA platform, provision of the necessary internet infrastructure, organization of the physical environment at home, following children's curricular and extracurricular activities, and motivating children to participate in lessons and other educational activities. The proportion of the female parents participating in the current study is high and almost half of the women are housewives.

The results related to the parents' opinions about their interest in distance education and fallowing their children revealed that the parents followed and were interested in what was done in the distance education process. It was also revealed that almost all of the parents followed how their children carried out distance education activities, enabled their children to follow their lessons during lesson hours and made efforts to 
motivate their children for distance education. Khamis, Dukmak \& Elhoweris (2008) stated that families are among the factors affecting students' motivation to learn. It can be said that parents play an important role in increasing children's motivation in a process which they are not accustomed to and in which they are only instructed through distance education.

However, it is positive that families followed the distance education process and did not use rewards / punishments during the process. The parents stated that the control of their children about the use of the internet became more difficult as lessons were taught in the virtual environment. In different studies, it has been reported that technology-addiction causes posture disorders (Ozdincler et al., 2019), developmental problems (Akbulut, 2013), physical inactivity (Hazar et al., 2017) and obesity (Muslu \& Gokcay, 2019). Today, the issue of internet security (Karakus et al., 2014; Celen, Celik \& Seferoglu, 2011) is frequently discussed. These risks can be cited as the reason for parents' concerns about the negative effects of the internet and being addicted to the screen and the need to control them.

The results related to the parents' opinions about their children's interest in distance education revealed that more than $80 \%$ of the parents followed their children willingly in distance education lessons. According to Motte (2013), e-learning has become an increasingly suitable option for many students who want to improve the quality of education for various reasons. It is noteworthy that children are more willing to attend EBA live class than TRT EBA TV and EBA platform. This shows the emotional attachment of children to their teachers. Children prefer to listen to their own class teachers instead of teachers they do not know. This gives rise to the question "Is central distance education or local (given by the school) distance education more effective?" In EBA live lessons, children can communicate online with their teachers and classmates in their schools. It can be concluded that for distance education, which is seen as the learning tool of the future, to be effective in primary and secondary school levels, stronger sense of real classroom environment should be generated.

The parents stated that their children's interest decreased because of the connection problems. In the studies on technology, it has been revealed that technical problems are frequently experienced in distance education (Bilgic \& Tuzun, 2015) and that these problems distract the attention of children. The parents' stating that their children's being closed at home due to the pandemic negatively affected their motivation for distance education indicates that physical and outdoor activities for children should also be planned in a distance education system that will be planned, except in extraordinary situations. This can be perceived as a sign that the interest in distance education may decrease gradually after the prolonged period of stay at home during the pandemic. In short, sustainability of the distance education system during a pandemic should also be considered as a subject of discussion.

Results regarding the parents' opinions about the development of their awareness of education show that the parents' awareness of their children's education increased. If this situation continues to show its effect during the normalization process, it means that we will have more conscious parents about the education of children. In addition, the parents' stating that they better understood the importance of teachers and the school during the pandemic is of great importance for the development of a better image of the teacher and school in the society. This may positively affect the participation of parents whose awareness of education has increased during the normalization process. It has been revealed in studies that school-family solidarity has an important effect on students' school success (Celenk, 2003; Gumuseli, 2004).

The results related to the parents' opinions about the home environment and access to distance education show that the home environment was sufficient for students to follow distance education, but arrangements had to be made in the home environment. Seventy five percent of the parents stated that they had technical problems and received support from the concerned people and institutions for the problems they experienced during the distance education process. As mentioned earlier, this is one of the known disadvantages of using technology (Oliveira, Penedo \& Pereira, 2018). Here, it is very important that the parents could receive support. Half of the parents found the internet quota given free of charge adequate and the other half did not find it inadequate, which might be related to their financial conditions.

Results regarding the parents' general opinions about on distance education show that their opinions about distance education are positive. As a matter of fact, the parents stated that distance education was useful for their children and that through distance education, their children did not get alienated to the school. The 
Minister of National Education in the Republic of Turkey made the following statement regarding distance education "our goal is to take the necessary measures for our children not to be alienated to the school" (MoNE, 2020c). The minister's stating that the main goal of distance education is to prevent children from getting alienated to the school is an indication that the MoNE has achieved its goal in distance education. The parents' thinking that distance education is a good application during the pandemic also shows that transition to distance education is a good decision. Another noteworthy result is that two-thirds of the parents $(66 \%)$ think that distance education cannot replace face-to-face education. Sahin \& Tekdal (2005) investigated 50 experimental studies in their meta-analysis study and stated that internet-based distance education is statistically more effective than face-to-face education. The same results have been obtained in experimental studies (Usta \& Mahiroglu, 2008; Yorganci, 2013). These results can be interpreted that distance education is successful when used as integrated to formal education and on a course basis, but its success is low if distance education is the only means of instruction.

In short, in the current study evaluating distance education during the pandemic on the basis of parents' opinions, it was determined that students needed the support of their parents in following lessons and that students were willing to take part in lessons. It was also revealed that because of such reasons as being closed at home and connection problems, students' motivation was negatively affected. During the pandemic, the parents' awareness of their children's education was found to have increased. While parents think that distance education will not take the place of face-to-face education, distance education during the pandemic was a good application and thus many children did not get alienated to the school according to them.

In the study conducted by Cakir, Karademir and Erdogdu (2018) on university students, the reasons for the dissatisfaction of the students having low and medium levels of motivation towards distance education were found to be lack of interaction, negative perceptions and dependence on traditional education. The fact that mass distance education systems are far from the school climate and offer limited communication and interaction opportunities for students reduces the interest and motivation of students. For this reason, these mentioned disadvantages should be taken into account when developing mass distance education tools. Minimizing the technical problems experienced and increasing the internet (data) security in live lessons will significantly increase the efficiency of the system. Offering free internet infrastructure to disadvantaged groups and increasing free mobile internet opportunities in the distance education process are measures to reduce inequality of opportunity. Repeating the research on mass distance education systems of different countries and including student views are recommended for future research. The current study is limited to the parents who could access the distance education system. It is known that there are people who cannot access distance education for reasons such as lack of suitable devices such as computers or tablets. Studies on who cannot access or partially access distance education across the country can be useful for determining the scope of distance education. Furthermore, similar research needs to be done for teachers, students and other stakeholders of distance education.

\section{BIODATA and CONTACT ADDRESSES of AUTHORS}

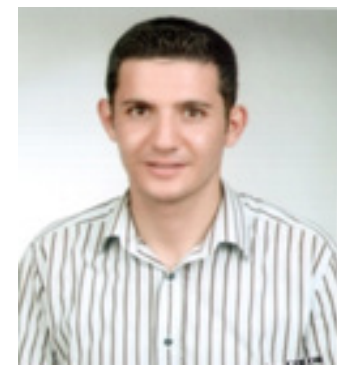

Dr. Engin DEMIR is an Assistant Professor at Vocational School of Health Services, Bandirma Onyedi Eylul University. Dr. Engin Demir gained his Ph.D. in Curriculum and Instruction in February 2018. His academic interest areas are learning and instruction, teacher training, higher education, meta-analysis, thinking skills, and values education. He has nearly 10 journal articles published in national and international indexes, 2 international book chapters, and other papers presented to international meetings.

Engin DEMIR

Department of Child Care and Youth Services, Vocational School of Health Services

Address: Bandirma Onyedi Eylul University, 10200, Balikesir, Turkey

Phone: +90 2667174606,

E-mail: edemirakademik@gmail.com 


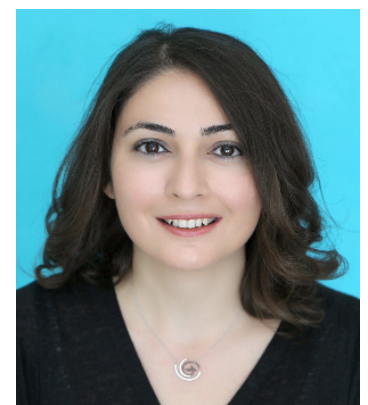

Dr. Cennet GOLOGLU DEMIR is an Assistant Professor at Faculty of Health Sciences, Bandirma Onyedi Eylul University. Dr. Cennet Gologlu Demir gained her Ph.D. in Curriculum and Instruction in March 2016. Her academic interest areas are teaching methods and technics, learning, curriculum development, attitudes, self-efficacy, and teaching mathematics. She has more than 10 journal articles published in national and international indexes, 2 international book chapters, and other papers presented to international meetings.

Cennet GOLOGLU DEMIR

Department of Child Development, Faculty of Health Sciences

Address: Bandirma Onyedi Eylul University, 10200, Balikesir, Turkey

Phone: +90 2667174506,

E-mail: gologlu.cennet@gmail.com

\section{REFERENCES}

Akbulut, Y. (2013). Developmental implications of computer and Internet use among children and adolescents. Trakya University Journal of Education, 3(2), 53-68. Retrieved from https://dergipark. org.tr/tr/pub/trkefd/issue/21474/230167

Aktay, S. \& Keskin, T. (2016). Analysis of educational information network (EBA). Journal of Education, Theory and Practical Research, 2(3), 27-44. Retrieved from http://ekuad.com/articles/egitimbilisim-agi-eba-incelenmesi.pdf

Ates, M., Cerci, A. \& Derman, S. (2015). Content analysis of Turkish course videos in educational informatics network. Sakarya University Journal of Education, 5(3), 105-117. doi:10.19126/suje. 18755

Bilgic, H. G. \& Tuzun, H. (2015). Yuksekogretim kurumlari web tabanli uzaktan egitim programlarinda yasanan sorunlar [Problems experienced in web-based distance education programs in higher education institutions]. $A U A d, 1(3), 26-50$. Retrieved from https://dergipark.org.tr/tr/download/ article-file/35550

Coskunserce, O. \& Isciturk, G. B. (2019). A case study on increasing students' awareness about the educational information network (EBA) platform. Journal of Qualitative Research Education, 7(1), 260-276. doi:10.14689/issn.2148-2624.1.7c1s.12m

Celen, F. K., Celik, A., \& Seferoglu, S. S. (2011). Children's internet usage and online risks they face. 13.th Akademik Bilisim Conference, (pp. 645-652). Malatya.

Celenk, S. (2003). The prerequisite for school success: home-school cooperation”. Elementary Education Online. 2(2), 28-34. Retrieved from http://ilkogretim-online.org.tr/index.php/io/article/ view/2046/1882

Cohen, L, Manion, L. \& Morrison, K. (2018). Research methods in education. Eighth edition. London: Routledge.

Cullinane, C. \& Montacute, R. (2020). COVID-19 and Social Mobility Impact Brief \#1: School Shutdown (Research Brief). University College London Institute of Education. Retrieved May 31, 2020, from https://dera.ioe.ac.uk/35356/1/COVID-19-Impact-Brief-School-Shutdown.pdf

Daniel, S.J. Education and the COVID-19 pandemic. Prospects (2020). doi:10.1007/s11125-020-09464-3

de Oliveira, M. M. S., Penedo, A. S. T., \& Pereira, V. S. (2018). Distance education: advantages and disadvantages of the point of view of education and society. Dialogia, (29), 139-152. doi: 10.5585/ Dialogia.n29.7661

Gumuseli, A.I. (2004). Ailenin katilim ve desteginin ogrenci basarisina etkisi [The effect of family participation and support on student success.]. Ozel Okullar Birligi Bulteni. 2(6), 14-17. 
Hazar, Z., Demir, G. T., Namli, S., \& Turkeli, A. (2017). Investigation of the relationship between digital game addiction and physical activity levels of secondary school students. Beden Egitimi ve Spor Bilimleri Dergisi, 11(3), 320-332. Retrieved from https://dergipark.org.tr/tr/download/articlefile/1028808

Huang, R.H., Liu, D.J., Tlili, A., Yang, J.F., Wang, H.H., et al. (2020). Handbook on facilitating flexible learning during educational disruption: the Chinese experience in maintaining undisrupted learning in covid-19 outbreak. Beijing: Smart Learning Institute of Beijing Normal University.

Kapidere, M. \& Cetinkaya, H. N. (2017). An evaluation of mobile application of education informatics network (EBA). International Journal of Active Learning, 2(2), 1-14. Retrieved from https:// dergipark.org.tr/tr/download/article-file/343832

Karakus, T., Cagiltay, K., Kasikci, D., Kursun, E., \& Ogan, C. (2014). Internet habits and safe internet use of children in Turkey and Europe. Education and Science, 39(171). Retrieved from http:// egitimvebilim.ted.org.tr/index.php/EB/article/view/1867/645

Karasar, N. (2019). Bilimsel arastirma yontemi kavram-ilke-teknikler [Concept-Policy-Techniques for Scientific Research Method] (34th Edition). Ankara: Nobel Yayinevi.

Khamis, V., Dukmak, S. \& Elhoweris, H. (2008). Factors affecting the motivation to learn among United Arab Emirates middle and high school students. Educational Studies, 34(3), 191-200. doi:10.1080/03055690701811297

Lynn, M. R. (1986). Determination and quantification of content validity. Nursing Research, 35(6), 382385. doi:10.1097/00006199-198611000-00017

MoNE, (2020a). Ministry of National Education statistics. Retrieved May 26, 2020 from http://sgb.meb.gov. tr/meb_iys_dosyalar/2019_09/30102730_meb_istatistikleri_orgun_egitim_2018_2019.pdf

MoNE, (2020b). Education information network (EBA). Retrieved May 26, 2020 from http://fatihprojesi. meb.gov.tr/icerik.html

MoNE, (2020c). Statement of the Minister of National Education. Retrieved May 26, 2020 from https:// www.meb.gov.tr/bakan-selcuk-23-martta-baslayacak-uzaktan-egitime-iliskin-detaylari-anlatti/ haber/20554/tr

Muslu, M., \& Gokcay, G. F. (2019). Risk factors causing obesity in technology-dependent children. Gumushane University Journal of Health Sciences, 8(2), 72-79. Retrieved from https://dergipark. org.tr/tr/pub/gumussagbil/issue/46106/482807

Ozdincler, A. R., Rezaei, D. A., Abanoz, E. S., Atay, C., Keles, Y. A., Tahran, O., \& Koroglu, F. (2019). The effect of technology addiction on posture and body awareness in school age children. Journal of Dependence, 20(4), 185-196. Retrieved from https://dergipark.org.tr/tr/pub/bagimli/ issue/48203/592742

Saklan, H. \& Unal, C. (2018). Technology friendly science teachers' views of educational information network (EBA). Necatibey Faculty of Education Electronic Journal of Science \& Mathematics Education, 12 (1). doi:10.17522/balikesirnef.437847

Sahin, M. C., \& Tekdal, M. (2005). Internet tabanli uzaktan egitimin etkililigi: Bir meta-analiz calismasi [Effectiveness of internet-based distance education: a meta-analysis study.]. 7th Akademik Bilisim Conference. Gaziantep

Sahin, M \& Erman, E. (2019). Evaluation of history teachers' opinions on the use of education information network (EBA). Mehmet Akif Ersoy University Journal of Education Faculty, 49, 256-275. doi:10.21764/ maeuefd.425608

Turker, A. \& Guven, C. (2016). High school teachers' utilization levels and opinions on the education information technologies network (EBA) project. Journal of Research in Education and Teaching. 5 (1), 244-254. Retrieved from http://www.jret.org/FileUpload/ks281142/File/ 27a.abdullah_ turker_.pdf 
Tuysuz, C. \& Cumen, V. (2016). Opinions of secondary school students about EBA course website. Usak University Journal of Social Sciences, 9 (3). Retrieved from https://dergipark.org.tr/tr/download/ article-file/228043

UNESCO, (2020a). COVID-19 educational disruption and response. Retrieved May 26, 2020 from https:// en.unesco.org/covid19/educationresponse

UNESCO, (2020b). National learning platforms and tools. Retrieved May 26, 2020 from https://en.unesco. org/covid19/educationresponse/nationalresponses

Usta, E. \& Mahiroglu, A. (2008). The effects of blended learning and online learning on academic achievement and learner satisfaction. Kirsehir Faculty of Education Journal, 9(2). Retrieved from http://kefad. ahievran.edu.tr/Kefad/ArchiveIssues/PDF/c1a4caed-f554-e711-80ef-00224d68272d

WHO, (2020). World Health Organization coronavirus disease dashboard. Retrieved May 18, 2020 from https://covid19.who.int/

Yorganci, S. (2015). The effects of web based distance education method on students' mathematics achievements. Kastamonu Education Journal, 23(3), 1401-1420. Retrieved from https://dergipark. org.tr/tr/pub/kefdergi/issue/22598/241409 